\title{
Syrup in Sachet
}

National Cancer Institute

\section{Source}

National Cancer Institute. Syrup in Sachet. NCI Thesaurus. Code C149974.

Medicinal product consisting of a syrup in a sachet. 